\title{
Family Company Governance Case
}

\author{
by Martin Hilb \\ (Switzerland)
}

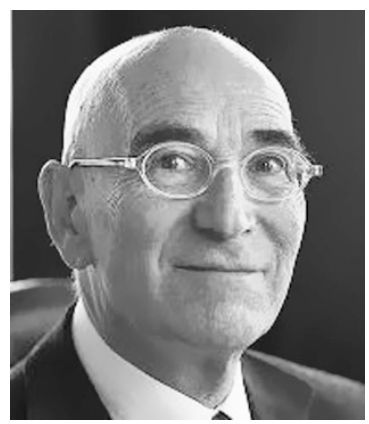

International Board Foundation and its International Center for Corporate Governance

All names and dates have been changed in this "living" case: Max Meier (61), a "humane" entrepreneur (with a cool head, a warm heart, and working hands), succeeded his father as baker in 1987 in Appenzell, Switzerland, and has over the last 33 years developed the family business into an internationally successful group of companies renowned for its chocolate specialties.

In 2018, the consolidated annual turnover reached $€ 250$ million. The group of 7 firms, employing 670 people, were acquired by Max Meier over a 20-year period.

Max Meier does not have any designated successor. He is owner, chairperson, president, CEO, and head of the family. His personality is characterized by a rare combination of entrepreneurial flair, creativity, sales talent, and high moral standards. His wife, the only other member of the board, is the financial manager. Together with Max, the couple constitute an ideal private and professional partnership.

Max and his wife have four children:

- Max junior (36) completed an apprenticeship in pastry making and then finished a law degree at the University of Geneva. Now he is responsible for exports in the firm and is based in Geneva.

See Martin Hilb: "New Corporate Governance," 5th Edition, Springer Heidelberg/New York 2016, pp. 26. 
- Monika (34), a Professor of Sociology at the University of Constance, resides in Kreuzlingen (Switzerland, at the Lake of Constance).

- Freddy (32) has a master's in finance from the Wharton School and is CEO of Schoko Ltd., a chocolate manufacturing company (acquired 2 years ago), one of the most successful sweets manufacturers in Entlebuch, Switzerland.

- Nicole (28) is an artist based in Paris. After her fine arts degree, she sojourned in Florence and Paris and furthered her studies in Vancouver and Rome.

Six months ago, Max Meier suffered a heart attack. He now asks you, as a competent, trustworthy, and old friend, how he should confront the issues of board composition and management appointment.

How would you advise him?

Open Access This chapter is licensed under the terms of the Creative Commons Attribution 4.0 International License (http://creativecommons.org/licenses/by/4.0/), which permits use, sharing, adaptation, distribution and reproduction in any medium or format, as long as you give appropriate credit to the original author(s) and the source, provide a link to the Creative Commons licence and indicate if changes were made.

The images or other third party material in this chapter are included in the chapter's Creative Commons licence, unless indicated otherwise in a credit line to the material. If material is not included in the chapter's Creative Commons licence and your intended use is not permitted by statutory regulation or exceeds the permitted use, you will need to obtain permission directly from the copyright holder.

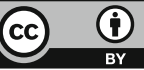

